\title{
Etxebizitzarako eskubidea
}

\author{
The right to housing
}

\author{
Aitziber EtXeZArRetA \\ Ekonomia Aplikatua i Saileko Irakasle Agregatua. UPV/EHU \\ Gezkiko Kidea \\ Etxebizitzarako Eskubidea
}

DOI: $10.1387 /$ reves.20523

Aurkibidea: 1. Etxebizitza eskubidearen errekonozimendu formala.2. Etxebizitza eskubidearen bermearen bilakaera EAEn. 2.1. Bilakaera historikoa: 2015 arteko Etxebizitza Plan Gidariak. 2.2. 2015eko Etxebizitza Legea 3/2015 Legea, ekainaren 18koa, Etxebizitzarena. 2.3. Azken Etxebizitza Plan Gidaria, 2018-20.-3. Erabilera lagapena etxebizitzan, politika publiko berrien ardatz? Esperientzia pilotua: Donostiako Txominen.-4. Bibliografia.—Eranskina.

\section{Laburpena}

Etxebizitza, ondasun berezia eta konplexua da inondik ere. Ondasun ekonomikoa izateaz gain, (kontsumo eta inbertsio ondasuna, alegia) edozein gizabanakorentzat oinarri-oinarrizko beharrizana da, edozein gizabanako eta familiaren bizitza garatzeko ezinbesteko baldintza. Etxebizitza, gainera, oinarrizko eskubidea ere bada nonnahi, giza-eskubidea eta eskubide soziala da aldi berean han hemengo arautegi eta legedietan.

Bestalde, etxebizitza, puzzle zabalago eta konplexuago bateko pieza da, gure herri eta hiriak osatzen dituen osagai nagusietakoa izaki. Ez dago etxebizitzarik hiririk gabe, ezta hiririk etxebizitzarik gabe (Muxi, Z, 2012: 151). Hain zuzen ere, gure inguruko etxebizitza sarea, hainbat faktorerekin hertsiki lotua dago: gure eredu ekonomikoaren bilakaera, lurralde antolamenduarena eta botere publikoek aurrera eramandako politikena, besteak beste.

Horren guztiaren ondorioz, etxebizitza eskubidea, beste eskubide sozial asko bete daitezen aurrebaldintza gisa ulertu beharra dago (osasuna, hezkuntza, eta abar). Eta era berezian hiriarekiko eskubidea, munduko biztanleriaren portzentaje hazkor bat hirietan bizi baita. Hirien antolamendua eta espazioa ez dira neutroak, eta ingurugiro ardatzetik, zein klabe sozialetik eta generotik ondo aztertu beharreko arloak dira. 


\begin{abstract}
Housing is a special, yet complex, commodity. Apart from being an economic good (i.e. a consumer and capital good), it is also a basic need for any person, and is an essential condition to be able to develop any person or family's life. Housing is also a fundamental right everywhere; it is both a human right and a social right embedded in the rules and laws of many places.

Furthermore, housing is a piece of a much broader and more complex puzzle, as it is one of the main elements that make up our towns and cities. There is no housing without a city, no city without housing (Muxi, Z, 2012: 151). In fact, the network of housing that surrounds us is closely linked to a number of factors: the evolution of our economic model, developments in spatial planning and the policies carried out by public authorities, among others.

For all these reasons, the right to housing must be understood as an essential prior condition to ensure many other social rights are respected (health, education, etc.). In particular, the right to the city must be respected, as a growing percentage of the global population now live in cities. City planning and space are not neutral, and they represent areas to be carefully studied both from an environmental perspective and from social and gender viewpoints.
\end{abstract}

\title{
1. Etxebizitza eskubidearen errekonozimendu formala
}

Nazioarteko eremuan, eskubide sozialen nazioarteko aitortza 1948an egin zuen Nazio Batuen Asanblada Orokorrak (declaración Universal de Derechos Humanos). Bertan, eskubide zibil eta politikoez gain eskubide sozial batzuk aitortzen dira, bizi-maila nahikoa izateko eskubidea, Osasuna eta ongizatea, eta etxebizitza izateko eskubidea, besteak beste. Geroztik, garatu egin dira aipatu eskubideak, eta etxebizitzaren kasuan, eskubide honek beste eskubide batzuekin dituen interrelazioak nabarmendu dira (pertsonaren duintasuna, intimitatea, Osasuna eta abar).

Etxebizitza eskubidea ere Europako Gutun Sozialean aitortua dago, eta honen Gutun Sozial berrikusian ere bai. Bertan, estatuei egozten zaie etxebizitzarako sarbidea errazteko zeregina, etxerik gabeko egoerak ekidin eta erraztekoa, eta baliabide nahikoak ez dituzten pertsonei etxebizitza prezio eskuragarriak lortzekoa.

Gutun Konstituzionaletan, batik bat II mundu gerratearen ostean onarturiko Konstituzioetan, Estatu Sozialaren forma konstituzionalizatu zen, eta etxebizitza eskubidea barne hartu zen. Era honetan, eskubide sozialak aitortzean, gizabanakoen oinarrizko beharrak desmerkantilizatu ziren, eta merkatuaren legetik at mekanismo birbanatzaileak hartatu ziren (Garrido, 2012: 23). 
Etxebizitza eskubidea, hortaz, eskubide sozial gisa garatu zen Ongizate Estatuen garapenean, baina Europako Estatu gehienetan, zailtasun handiekin. Hain zuzen ere, Europako herrialde gehienetan, etxebizitzaren adarra Ongizate Estatuaren adarrik ahulenetakoa izan da. Estatu Konstituzional gehienak, espainola kasu, etxebizitzarako eskubide konstituzionala sartu zuten, baina eduki ahulekoa.

Azken batean, herrialde gutxi batzuen salbuespenarekin, ez da existitu etxebizitza oinarrizko eskubidea babestuko zukeen balio konstituzionaleko printzipiorik, Jabegoaren kasuan eman den gisan. Horren partez, balio konstituzionaleko helburu gisa finkatu da, botere publikoei esku hartzeko mandatuarekin (Garrido, 2012:25).

Etxebizitza eskubidearen errekonozimendua Espainian, Konstituzioaren 47 artikuluan dago:

"Espainol guztiek bizitza duin eta egokizko bat izateko eskubidea dute. Botere publikoek behar diren baldintzak bultzatuko dituzte eta arau erakoak ezarriko eskubide hau egiaztatzeko, lurraren erabilpena arautuz interes orokorraren arabera espekulazioa baztertzeko. Erkidegoak erakunde publikoetako hiri ekintzek dakartzaten plusbalietan parte hartuko du.»

Azkenik, zenbait autonomia erkidegok etxebizitza eskubidean haratago joateko eta galdagarri bihurtzeko saiakerarik egin dute azken hamarkadan: hala Andaluzia, Katalunia eta Euskal Autonomia Erkidegoak, eta laster onartuko direnak, Aragonen kasu. Eta honen atzean etxebizitza benetako eskubide efektibo bat izateko saiakera dago, helburu bat izatetik haratago.

\section{Etxebizitza eskubidearen bermearen bilakaera EAEn}

\subsection{Bilakaera historikoa: 2015 arteko Etxebizitza Plan Gidariak}

Etxebizitza eskubidearen bermeari dagokionez, EAEn milurteko berriarekin ahalegin hazkorra egin zen etxebizitzaren arazoari bultzada publikoa zuen irtenbidea bilatzeko. Honela, etxebizitza plan zuzendariak bihurtu ziren aipatu bultzada horren ardatz nagusi (2002-05, 2006-09, 2010-13, 2013-16), eta ziklo ekonomiko hedakorreko urteetan, esfortzu ekonomiko progresiboa egin zen zentzu honetan, hain zuzen ere, 2002-05 eta 2006-09 Etxebizitza Plan Gidarietan bultzada handia eman zitzaion etxebizitza politikari. Aldiz, depresio handiaren albotik aurkako joera gailendu da eremu honetako alderdi gehienetan ere. 


\section{Grafikoa}

Etxebizitza Plan Zuzendarien errepasoa, edukitze-eraren arabera (2002-2016)

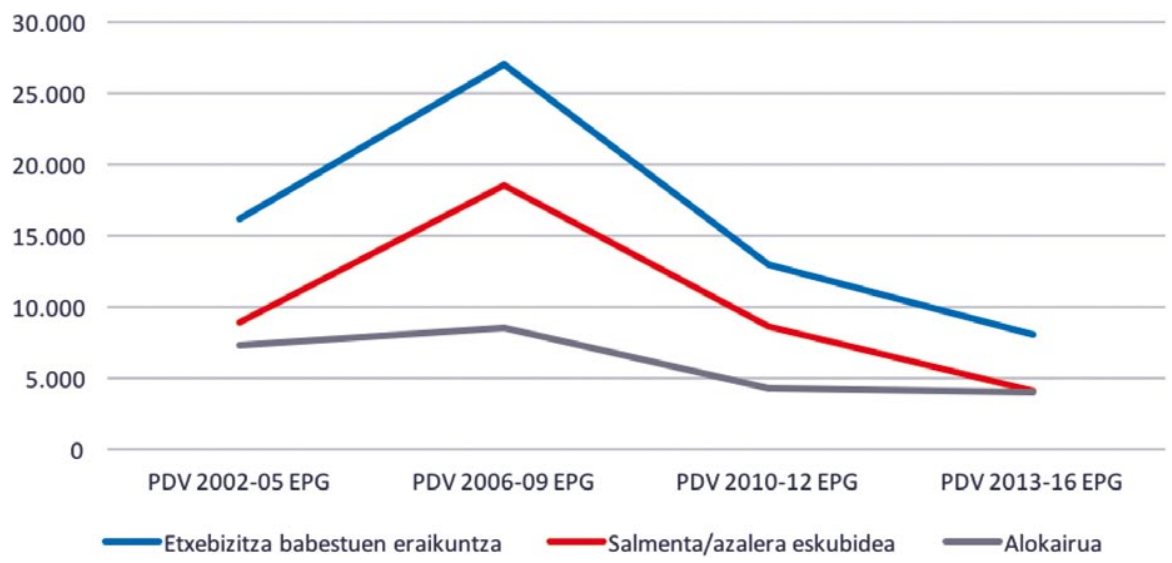

Iturria: autoreak egina, Ingurumen, Lurralde Plangintza eta Etxebizitza Sailaren datuetatik.

Hala, etxebizitza babestuen eraikuntza, 2002-05 Plan Gidarian 16.200 izatetik 2006-09an 27.000 izatera pasa zen. Etxebizitza berri babestuen eraikuntza bilakatu zen, hain zuzen ere, gure testuinguruko etxebizitza politikaren ardatz nagusia, eta etxebizitza merkatuan eragiteko asmoz ekindako bide zehatz bat. Horrela, hazkunde ekonomiko garaietan baliabide eta helburu handiagoz hornitu baziren ere Etxebizitzarako Plan Gidariak, etxebizitza berri babestuen eraikuntzan zentraturik, krisiaren ostean aurrekontu murriztuak eta helburu txikitzeak etorri ziren. Hala, 2010-12 Plan Gidarian erditik behera jaitsi zen eraikuntzako helburua, $12.950 \mathrm{era}$, eta 2013-16ko Plan Gidarian, are gehiago murriztu zen, 8.000ra.

Eduki-erari edo tenentzia errejimenari dagokionez, Plan Gidari guztietan gailendu dira jabetzan (edota gero azalera-eskubidean) esleitutako etxebizitzak. Honi loturik, 1. Taulak adierazten digu alokairuak eraikuntza osoaren gainean duen portzentajea 2002-05ean \%45,1ekoa izan zela, 2006-09ean \%31,5ekoa, 2010-12an \%33,2koa eta 2013-16an $\% 49$,4koa. 


\section{Taula}

Etxebizitza Plan Gidarien errepasoa (edukitze-era), (2002-2016)

\begin{tabular}{lrrrc}
\hline & $2002-05$ & $2006-09$ & $2010-12$ & 2013-16 \\
\hline Etxebizitza babestuen eraikuntza & 16.200 & 27.000 & 12.950 & 8.000 \\
Salmenta / azalera eskubidea & 8.900 & 18.500 & 8.650 & 4.050 \\
Alokairua & 7.300 & 8.500 & 4.300 & 3.950 \\
\hline Alokairuaren \% eraikuntza osoan & $\% 45,1$ & $\% 31,5$ & $\% 33,2$ & $\% 49,4$ \\
\hline
\end{tabular}

Iturria: autoreak egina, Ingurumen, Lurralde Plangintza eta Etxebizitza Sailaren datuetatik.

Bilakaera horren beraren aurpegi desberdinak adierazten ditu atxikitako 2. Taulak, bestalde, etxebizitza babestuen eraikuntzako datuaren bilakaeraren gora-behera aztertzen dugunean planez plan (16.200 etxebizitza eraiki 2002-05ean, 27.000 etxebizitza eraiki 2006-09ean; eta 12.950 2010-12an eta 8.000 2013-16an, hurrenez hurren). Bilakaeraren patroi berbera errepikatzen da lurzoru erosketako datuei erreparatzen diegunean ere, 22.600 eta 24.000 , hurrenez hurren goraldi garaietan, eta 12.100 eta 3.000, hurrenez hurren krisialdiaren albotik.

Aldiz, etxebizitza hutsa mugiarazteko programek eta birgaikuntzako eskuhartzeek alderantzizko bilakaera jasan dute, eta ugaritu egin dira krisialdi ekonomikoaren osteko planetan (etxebizitza hutsari loturiko zifren bilakaera 5.000 eta 5.000 izan zen goraldi garaian, eta krisialdi garaian, 6.817 eta $8.080 \mathrm{koa}$; eta, hurrenez hurren, birgaikuntzako eskuhartzeak honela zenbatu dira: $29.000,51.250,52.900$, eta 73.400 ).

\section{Taula}

Etxebizitza Plan Zuzendarien errepasoa, partida nagusiak (2002-2016)

\begin{tabular}{lrrrr}
\hline & $2002-05$ & $2006-09$ & $2010-12$ & 2013-16 \\
\hline Etxebizitza babestuen eraikuntza & 16.200 & 27.000 & 12.950 & 8.000 \\
Lurzoru erosketa & 22.600 & 24.000 & 12.100 & 3.000 \\
Etxebizitza Hutsa (BIZ+ASAP) & 5.000 & 5.000 & 6.817 & 8.080 \\
Birgaikuntza & 29.000 & 51.250 & 52.900 & 73.400 \\
\hline
\end{tabular}

Iturria: autoreak egina, Ingurumen, Lurralde Plangintza eta Etxebizitza Sailaren datuetatik. 
Bestalde, agente sustatzaileei erreparatuz, Sailek zuzenean sustaturiko etxebizitzen beherakada, 2006-09ko 10.950 etxebizitzatik, 2010-12ko 6.700era eta 2013-16ko 3.600ra izan zen. Baina aldiz, udaletxeek zuzenean sustaturiko etxebizitzen gainbehera askoz nabarmenagoa izan zen, 200609ko 10.950etik 2010-12ko 1.550 eta 2013-16ko 1.000ra hain zuzen ere.

\section{Taula}

Etxebizitza Plan Zuzendarien errepasoa (agente sustatzailearen arabera)

\begin{tabular}{lcccc}
\hline & $2002-05$ & $2006-09$ & $2010-12$ & $2013-16$ \\
\hline Etxebizitza babestuen eraikuntza & 16.200 & 27.000 & 12.950 & 8.000 \\
Sailak/Sozietateak & 8.350 & 10.300 & 6.700 & 3.600 \\
Udaletxeak & 7.850 & 10.950 & 1.550 & 1.000 \\
Pribatuak & - & 5.750 & 4.700 & 3.400 \\
\hline
\end{tabular}

Iturria: autoreak egina, Ingurumen, Lurralde Plangintza eta Etxebizitza Sailaren datuetatik.

Babesturiko etxebizitzen bilakaerak, laburbilduz, 2000. Urtetik aurrera goranzko joera azaldu zuen, 2007an goia joz: 7.310 babesturiko etxebizitza hasi ziren. Orduz geroztik beherantz joan zen babesturiko etxebizitzen eraikuntza, 2015 urtean mailarik apalena errejistratu arte: 1.081 etxebizitza babestu hasi ziren. 2016 urtean 1.331 babesturiko etxebizitza berri hasi ziren.

Alokairu erregimenean berriz, patroia nahiko antzerakoa izan da, baina beti ere, maila apalagotan: 2007an eman zen errejistrorik altuena 1.842 etxebizitza berri hasi zirenean alokairu sektorera bideratzeko, eta 2015ean errejistrorik apalena 185 etxebizitza berri hasi zirenean EAEko alokairu publikoaren parkea elikatze aldera. 2016an 364 etxebizitza hasi ziren aipatu zioarekin.

Hala, etxebizitzan egindako gastu publikoari erreparatzen badiogu, garbi ikusten da 2001 urtetik 2010era emaniko goranzko joera (117 milioi eurotik 362,7 milioi eurora igo zen etxebizitzan egindako gastu publiko osoa $^{1}$, Ingurumen, Lurralde Plangintza eta Etxebizitza Saila, 2018).

Zentzu honetan, 2010-13 Plan Gidariak, eta ondoren, 2013-16 Plan Gidariak austeritate garaiak islatu zituzten, eta depresio handiaren ostean etxebizitza politikan eginiko gastua nabarmen erori zen plan Gidarien laburpenetan garbi ikusten den moduan.

Ondorioz, azken hamarkadan babesturiko alokairuko merkatuan ez da goraldi esanguratsurik izan, azken grafikoan ikusten den moduan. Hortaz,

\footnotetext{
${ }^{1}$ Gastu publiko osoan barne hartzen dira honoko gastuok: inbertsio zuzenak, transferentziak eta kapital diru-laguntzak, eta gastu korrontea.
} 
2015eko Etxebizitza Legearen helburuei erantzuteko eta azken Plan Gidariaren helbururei erantzuteko dimentsio nahikorik ez duen alokairu etxebizitzako parkea dugu oraindik ere EAEn, hurrengo puntuetan frogatuko dugun moduan.

\section{Taula}

Biziguneko etxebizitza parkearen bilakaera (2007-2016)

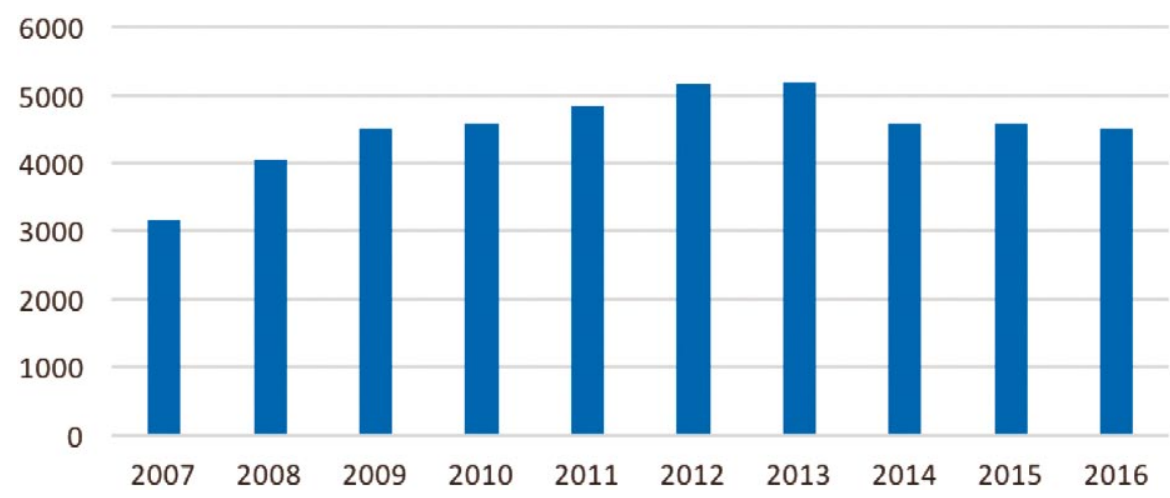

Iturria: autoreak egina, Ingurumen, Lurralde Plangintza eta Etxebizitza Sailaren datuetatik.

\subsection{5eko Etxebizitza Legea 3/2015 Legea, ekainaren 18koa, Etxebizitzarena}

Etxebizitzaren eskubidean nolabaiteko hitoa izan zen eskuhartze publikotik eginiko etxebizitza esleipen guztietan jabegotik azalera-eskubidera pasatzea (Hoekstra et al., 2010), eta neurri bereko edo handiagoko hitoa izan da Etxebizitza Eskubide subjetiboa onartzeko Legea onartzea EAEn, hainbat lege proiekturen eta zirriborroren ostean (Etxezarreta eta Merino, 2013).

Lege honen bertutez eskubide formal bat galdagarri edo subjektibo batera pasatzeko pausoa eman zen, saiakera hutsal eta eztabaida askoren ostean. Honek erabat baldintzatuko du ondorengo etxebizitza politika, baita, hain zuzen ere, horren ostean indarrean jarri den Etxebizitza Plan Gidaria ere (EPG 201820; Ingurumen, Lurralde Plangintza eta Etxebizitza Saila, 2018)2 .

Aipatu Legea 10 kapitulotan dago antolatua, 93 artikulutan garatua eta lau xedapen gehigarritan (gehi zazpi xedapen iragankor eta hiru xedapen indargabetzaile eta bederatzi azken xedapen).

2 2015eko Etxebizitza Legearen aplikazioa progresiboa izango zela aurreikusi zen, eta lehenengo urtean 3 kide edo gehiagoko etxeguneek eska zezaketen, bigarren urtean 2 kideko edo gehiagoko etxeguneek eta hirugarren urtean, kide bateko edo gehiago etxeguneek. 
Zenbait puntu azpimarratzearren, ondorengoak:

—Etxebizitza duin eta egoki bat legez okupatzeko eskubide subjektiboa definitzea. Bertan, Eskubide subjektiboa betetzeko moduak eta exijitzeko baldintzak zehazten dira, besteak beste, bizitoki egonkorrik ez izatea, babesturiko etxebizitzen eskatzaile erregistratua izatea (behar den antzinatasunaz), urteko dirusarreren gehienezko muga ez gainditzea edo/eta exekuzio prozesua bat pairatzea (9. artikulua).

-Etxebizitzaren funtzio sozialaren bermea konpromiso. Bertan, etxebizitza hutsaren gaineko kanona ezarri zen, urteko eta metro karratu bakoitzeko 10 euroko isuna aurreikusiz, frogatutako etxebizitza hutsen gainean (57. artikulua)

- Desjabetzea edo jabetza kentzea funtzio soziala betetzen ez duten etxebizitzen kasuan (63. artikulua)

Gogorarazi behar da, hala nola, lege honetako zenbait artikulu (batik bat etxebizitzaren funtzio sozialaren kunplimenduarekin loturikoak, etxebizitza hutsa eta desjabetzeak; hau da, eskubide negatiboarekin lotuak direnak), inkonstituzionaltasun errekurtsoa jaso zutela, 1643-2016 zenbakiduna ${ }^{3}$.

Aurrekoez gain, gainerako beste zenbait artikulu esanguratsu eranskin batean jaso dira (ikus artikuluaren azken orrietan atxikia), eta hirugarren xedapen gehigarrian dago jasoa «Irabazi asmorik gabeko elkarteek bizitegi-multzoak sustatzea edo eskuratzea erabilera-lagapeneko araubidean». Bertan, lehenengo aldiz era berritzailean sartu da gure marko juridikoan Andel eredua edo erabilera -lagapeneko araubidea (cesión de uso) etxebizitzaren alorrean.

Hala, etxebizitzen kooperatibei beste era bateko aplikazioa irekitzen zaie, hain zuzen ere, "kasu horretan, elkartea izango da higiezin-multzoaren jabea, eta jabari osoa izango du haren gainean, edo eraikitzeko aukera ematen dion beste eskubideren bat. Elkartekideak pertsona fisikoak izango dira, eta elkarteak esleitzen dizkien etxebizitzak eta lokalak erabiltzeko eskubidea izango dute baldin eta esleipena haren estatutuetan eta barne-antolakuntzako arauetan aurreikusitako erregelen arabera egiten bada».

Beraz, kooperatibak ez dira izango hemendik aurrera etxebizitzen sustapen eta eraikuntza prozesuan sar daitekeen agente trantsitorio bat, baizik eta etxebizitzaren erregimena ulertu eta bizitzeko beste formula baten hasiera formala inplikatuko du (Etxezarreta et al., 2018, Etxezarreta et al., 2013). Formula honen bidez kooperatiba izango da behin-betiko etxe-multzoaren jabea, eta bertako bazkideak, etxeen erabiltzaile (Merino, 2013). Honek, zalantzarik gabe, jabegoa eta alokairuaren bitarteko formula bati bidea irekitzen dio eta erabateko berrikuntza da gure testuinguruko etxebizitzaren tenentzia esparruan.

32018 ko urria bitartean ez dira indarrean jarri. 


\subsection{Azken Etxebizitza Plan Gidaria, 2018-20}

2018 urtetik aurrera eskatzaile guztiek exiji zezaketen eskubidea da, eta gainera, 2018-20ko Etxebizitza Plan Gidaria, Etxebizitza buruzko Legearen (ekainaren 18ko 3/2015) barruan egindako lehena da. Planaren aurkezpenean argi uzten den moduan, 2018-20 Plan Gidariak Etxebizitzaren Legeak barne hartzen dituen helburuen kunplimendua bere gain hartzen du.

Jada auzitegietan eska daitekeen eskubidea da, beraz, eta alokairuko etxebizitza edo ostatua emanez (ahal den kasuetan), edo prestazio ekonomiko baten bidez (lehenengo bidetik ezin denean) gauza daiteke. Ordain ekonomikoa, behin-behineko irtenbide gisa agintzen da etxebizitza eman ezin zaien pertsona eta familien kasuan, baina alokairu publikoko parkearen mugak nabarmenak izanik (frogatua geratu da aurkezpen honetako bigarren puntuan), bide hau ezinbestekoa izango dela aurreikusi daiteke.

\section{Taula}

2018-20 aldirako Etxebizitzaren Gida Planean jasotako erronkak eta ardatz estrategikoak

\begin{tabular}{l|l}
\hline \multicolumn{2}{c}{ Planaren erronkak } \\
\hline 1. erronka & Etxebizitza-legea garatzea eta eskubide subjektiboa bermatzea \\
\hline 2. erronka & Babestutako alokairua eta sarbideko formula berritzaileak areagotzea \\
\hline 3. erronka & Bizitegi-parkearen birgaitzea eta etxebizitza hutseko erabilera bultzatzea \\
\hline 4. erronka & Etxebizitza-politiken eraginkortasuna hobetzea: koordinazioa eta ebaluazioa \\
\hline 1. ardatza & Etxebizitza-parkearen alokairua bultzatzea \\
\hline 2. ardatza & Babestutako etxebizitza parkearen kudeaketa eraginkorrean aurrera egitea \\
\hline 3. ardatza & $\begin{array}{l}\text { Ikuskatzea eta esleipen-prozedurak eta babestutako etxebizitzarako sarbi- } \\
\text { deko baldintzak aldatzea }\end{array}$ \\
\hline 4. ardatza & $\begin{array}{l}\text { Eraikinen mantenua eta birgaitzea sustatu, egungo parkeetako eskuraga- } \\
\text { rritasun eta eraginkortasun energetikoa hobetuz }\end{array}$ \\
\hline 5. ardatza & $\begin{array}{l}\text { Etxebizitzen berrikuntzan aurrera egin, modelo ezberdinak ezarriz gaz- } \\
\text { teen eta kolektibo ezberdinen beharrei egokitzen direnak }\end{array}$ \\
\hline 6. ardatza & $\begin{array}{l}\text { Kudeaketa hobea izaten laguntzen duen kolaborazio sareak eta politika } \\
\text { sektorial ezberdinen integrazioa sortzea }\end{array}$ \\
\hline
\end{tabular}

Iturria: Ingurumen, Lurralde Plangintza eta Etxebizitza Saila (2018), Etxebizitzaren Gida Plana 2018-20 Plan Director de Vivienda, Eusko Jaurlaritza, Vitoria-Gasteiz. 
Honen arabera, berriro ere alokairu publikoa bultzatzea beharrezkoa dela jasotzen da 2018-20 Plan Gidariaren helburu nagusietan ${ }^{4}$, bigarren erronkak esaterako alokairu publikoa eta sarbide era berritzaileak ditu jomuga (ikus 2. Taulan). Bertan, alokairuetara zuzentzen diren baliabideen $\%$ gehikuntza beharra jasotzen da, eta zehatzago, baliabideen \%80 (birgaitzea kanpo utzita) alokairuaren sustapenera zuzentzeko erronka. Baita ere, bigarren erronka honetan barnehartzen da etxebizitzetarako sarbide malgutasuna ordezko formulen bitartez, hau da: co-housing, etxe-partekatuak, eta erosketaren eta alokairuaren arteko bitarteko formulak.

Bestetik, Planaren bosgarren ardatz estrategikoak hauxe dio: «etxebizitzen berrikuntzan aurrera egin, modelo ezberdinak ezarriz herritar gazteen eta kolektibo ezberdinen beharrei egokitzen direnak». Bertan gazteei emantzipatzen laguntzeko eta beste kolektiboak etxebizitza batean sartzen laguntzeko ekintzak proposatzen dira, eta baita ere zahartzen ari diren pertsonei bizimodua erraztuko dieten inguruneak sustatzeko ekimenak bultzatzea ${ }^{5}$. Azken honi dagokionez, elkarlaneko etxebizitzen ekimenak bultzatzea, cohousing-a aipatzen da (senior cohousing litzatekeena, Etxezarreta et al., 2016).

Gazteei zuzenduriko neurrien artean, berriz, 5.1.4. ekintzan belaunaldien arteko bizikidetza-ekimenei buruzko esperientzia pilotua abian jartzea, eta 5.1.3. ekintzan erabilera-lagapeneko kooperatiben sorrera sustatzea aipatzen da, eta horretarako esperientzia pilotua abian jarriko da.

\section{Erabilera lagapena etxebizitzan ${ }^{6}$, politika publiko berrien ardatz? Esperientzia pilotua: Donostiako Txominen}

Berriki proiektu pilotu bat iragarri du Eusko Jaurlaritzak: Donostiako Txomin Enea auzunean lurzorua erosi dute, erabilera-lagapeneko kooperatiba bati esleitzeko 7 . Honela, etxebizitza kooperatiben eredua probatuko du Jaurlaritzak, kooperatiba eredu berri batena hain zuzen ere.

${ }^{4}$ Alokairu publikoa bultzatu beharra aurreko Plan Gidarietan ere luze jasotako helburua da. Nolanahi ere, historikoki Plan Gidariak aitortutako alokairu helburuak nahiko portzentaje laburrean bete izan dira (Plan Gidari askotan \%50 inguruko exekuzio portzentajea izan dute), eta aldiz, jabegoan edo eskumen lagapenean proposaturikoak \%100 gainditu izan dute exekuzio portzentajeetan, aurreko Plan Gidarien errepasoetan argitzen denez.

5 Familia ereduak eraldatzen ari dira, zahartzen diharduten gizarteetan bizi gara, eta fenomeno hauen ondorioz gero eta zaintza eta etxebizitza formatu desberdinak ere beharko ditugu, behar sozial hazkor horiei erantzunak emateko

6 Viviendas en Cesión de Uso.

7 https://www.berria.eus/paperekoa/1857/013/001/2017-11-24/etxebizitza_kooperatiben_ eredua_probatuko_du_jaurlaritzak.htm 
Testuinguru geografiko hurbilekoan eredu berritzaile gisa aurkeztu da, nahiz eta eredu honek erreferente sendo eta esperientziadunak badituen, Danimarkan kasu. Kooperatiba eredu honetan, bazkide izango direnek diru kopuru bat jarriko dute, eraikina eraikitzeko. Behin bertan bizi direnean alokairua ordainduko dute. Hau jabego eta alokairuaren erdibideko formula da; hain zuzen ere, etxebizitzen jabetza kooperatibaren eskuetan mantentzen da beti, eta sozioak, erabiltzaile-inkilino dira, era egonkorrean. Bizilagunen batek etxebizitza utzi nahi badu ekarpena itzuliko diote eta bazkide berri bat sartuko litzateke bere tokian (Etxezarreta et al., 2016, Etxezarreta et al., 2018).

Donostiako hau eredu berritzaile bat administraziotik aplikatzeko lehenengo saiakera da, eta aurrera badoa, agian EAEko etxebizitza politika publikoetan esparru berri bat ireki dezake, aurretik martxan dauden politiken osagarria. Hala balitz, alokairu sozialeko etxebizitzak sustatzeaz gain, etxebizitza huts pribatuak alokairuko esparrura erakartzeaz gain, (eta birgaikuntza eta inspekzioan egindako ekintzez gain), jabego eta alokairuaren dikotomiatik haratago garamatzan ekonomia sozialeko formula bat gure eremu geografikoan txerta daiteke.

Areago, esperientzia pilotu hau zahartzen ari den segmentura ere ekartzea gomeni da (senior co-housing), etxebizitzaren gida planak aitortzen duen moduan. Hain zuzen ere eredu berritzaile hau zahartzen ari den gizarteak dituen etxebizitza beharrak, baina baita ere familia-eredu berriak, zaintzen afera eta genero berdintasuna bezalako gai diziplinarteko eta multidimentsionalak jotzen baititu (Emakunde, 2016). Azken batean, Espainian azken urteotan sortu diren co-housing ekimenen artean, senior segmentuan emanikoak izan dute arrakasta gehien (Etxezarreta et al., 2018).

\section{Bibliografia}

Emakunde (2016): Arquitecturas del Cuidado, Instituto Vasco de la mujer, Vitoria-Gasteiz.

Enplegu eta Gizarte-Politiketako Saila (2016), Plan Director de Vivienda, 2013-16, Eusko Jaurlaritza, Vitoria-Gasteiz.

Etxebizitza, Herri-Lan eta Garraio Saila (2013), Plan Director de Vivienda y Regeneración Urbana 2010-13, Eusko Jaurlaritza, Vitoria-Gasteiz.

Etxezarreta. A., G. Cano eta S. Merino (2018), Las cooperativas de viviendas de cesión de uso: experiencias emergentes en España, CIRIEC-España, Revista de Economía Pública, Social y Cooperativa, n. ${ }^{\circ}$ 92, pp.

Etxezarreta. A., G. Cano eta S. Merino (2015): «Social innovation and social economy: a new framework in the Spanish housing context», paper presented at ENHR conference in Lisbon 2015 
Etxezarreta. A. eta S. Merino (2013), «Las cooperativas de vivienda como alternativa al problema de la vivienda en la actual crisis económica», REVESCO, Revista de Estudios Cooperativos, vol. 113, 92-119.

Etxezarreta, A. (2008), "Avances en el derecho ciudadano a una vivienda digna. Reflexiones sobre el anteproyecto de ley de la CAPV», XL Jornadas de Economía Crítica, Bilbao, 27-29 de marzo 2008.

Garrido, P. (2012), Significado del derecho a la vivienda en el siglo XxI, en Unceta, A. y P. Garrido (editores), De la vivienda a la ciudad: percepciones, retos y oportunidades, Ascide, Zarautz.

Hoekstra, J., I. Heras eta A. Etxezarreta (2010), Recent changes in Spanish housing policies: subsidized owner-occcupancy dwellings as a new tenure sector?, Journal of Housing and the Built Environment 25 (1), 125-138.

Ingurumen, Lurralde Plangintza eta Etxebizitza Saila (2018), Etxebizitzaren Gida Plana 2018-20 Plan Director de Vivienda, Eusko Jaurlaritza, Vitoria-Gasteiz.

Merino, S. (2013): «La cooperativa de viviendas como administradora de bienes comunes», Revista Vasca de Economía Social, 9, 101-110.

- (2013) "Cooperativas de Viviendas», Tratado de Derecho de Cooperativas (Director Juan Ignacio Peinado), Tomo II, 1393-1421. Valencia: Tirant lo Blanc.

Muxi, Z. (2012), La ciudad no es sin vivienda y la vivienda no es sin ciudad, en Unceta, A. y P. Garrido (editores), De la vivienda a la ciudad: percepciones, retos y oportunidades, Ascide, Zarautz.

Otxoa-Errarte, R. (2016), «Reforma del régimen de las cooperativas de viviendas en Euskadi: de la promoción especulativa encubierta a la cooperativa con cesión de uso", Comunicación presentada en el XVI Congreso de Investigadores en Economía Social y Cooperativa, de CIRIEC-España, Valencia, de 19 al 21 de octubre 2016. 


\section{Eranskina}

\section{Taula}

Zenbait artikulu esanguratsu

\section{I. kapitulua}

1. artikulua. Xedea

Konstituzioaren 47. artikuluko agindua garatzeko eta betetzeko, eta Autonomia Estatutuaren 10.31 artikuluan aitortutako eskumen oso eta esklusiboak gauzatuz, lege honen xedea da etxebizitza duin eta egokia izateko eskubidea arautzea Euskal Autonomia Erkidegoan.

Botere publikoek aipatutako eskubidea gauzatzeko egoki diren neurriak sustatuko dituzte, honako irizpide hauen arabera:

a) Etxebizitza egoitza, bizileku edo etxe egonkorra izatea, eta haren hartzaile edo erabiltzaileek modua edukitzea bertan duintasunez bizitzeko, beren intimitatea babesteko eta familia- eta gizarte-harremanez gozatzeko, hura okupatu eta erabiltzeko legezko eskubidea dutelarik.

b) Tamainari dagokionez, bertan biziko den pertsona, familia edo bizikidetza-unitatearen ezaugarrietarako egokia izatea, horien bizitzako aldiak eta bizitegi-premiak kontuan hartuta eta gizonen eta emakumeen arteko tratu- eta aukera-berdintasuna errespetatuta.

c) Eraikinen antolamenduari buruzko legerian eta aplikatu beharreko araudi teknikoan aurreikusitako baldintza objektiboak betetzea, funtzionaltasunari, bizigarritasunari, segurtasunari eta osasungarritasunari dagokienez. 


\section{II kapitulua. Etxebizitza duin eta egoki bat legez okupatzeko eskubide subjek- tiboa}

\section{9. artikulua. Eskubide subjektiboa betetzeko moduak eta exijitzeko baldintzak}

Etxebizitza duin eta egoki bat legez okupatzeko eskubidea bete ahal izango dute horretarako eskumena duten euskal administrazio publikoek, alokairuan eskura jarrita etxebizitza babestu bat edo bizitoki babestu bat, edo baita etxebizitza libre bat ere baldin eta erabilgarri badago bitartekaritza-programaren batengatik edo beste arrazoi batzuengatik, kasu bakoitzean egoki den errenta edo kanonarekin.

Etxebizitza edo bizitokirik ezean, eta izaera subsidiarioarekin, eskubidea prestazio ekonomikoen sistema bat ezarrita bete ahal izango da.

Administrazio publiko eskudunei etxebizitza-eskubidea exijitzeko, honako baldintza hauek guztiak bete beharko dira:

a) Etxebizitza edo bizitoki egonkor edo egokirik gabe egotea. Etxebizitza egokia ez izatearen arrazoiak izan daitezke bizigarritasuna, tamaina, ahalmen ekonomikoa, arrazoi juridikoak edo eguneroko bizitegi normalizatua izatea zailtzen duen beste edozein.

b) Etxebizitza Babestuen eta Zuzkidura Bizitokien Eskatzaileen Erregistroan baliozko eran izena emanda egotea, alokairuko etxebizitzaren eskatzaile gisa soilik, erregelamenduz ezarriko den gutxieneko antzinatasunarekin, zeinaren kontaketarako errespetatu egingo baita lege hau indarrean sartzean jada eskuratuta eta indarrean dagoena.

c) Urteko diru-sarrerak erregelamenduz ezarritako mugen artean daudela frogatzea.

d) Hipoteka-exekuzioen edo errenta ez ordaintzearen ondoriozko etxegabetze-prozeduretan sartuta eta gizarte-larrialdiko egoera berezietan dauden pertsonen etxebizitza-premiaren kasuetan, etxebizitzaren erabileraz aldi baterako desjabetzeko prozedura aplikatu ahal izango da, 74 eta 75 . artikuluetan ezarritakoaren arabera eta aurreko paragrafoan adierazitako baldintzak exijitzekoak izan gabe. 


\section{7. artikulua. Jenderik gabeko etxebizitzaren kanona}

1. Etxebizitzaren jabetzaren funtzio soziala bete dadin sustatze aldera, kanon bat ezartzen da jenderik gabe dauden etxebizitzen gainean. Kanon hori zergaz bestekoa izango da, jenderik gabeko etxebizitza deklaratuta daudenen gainean ezarriko dute Euskal Autonomia Erkidegoko udalek, eta kontzeptu horrengatik lortutako diru-sarrerek lurzoruaren udal lurzoru-ondarea hornituko dute.

2. Kanona pertsona fisikoei nahiz juridikoei ezar dakieke, baita jaraunspen jasogabeei, ondasun-erkidegoei eta bestelako entitateei ere baldin eta, nortasun juridikorik izan ez arren, unitate ekonomiko edo ondare bereizia osatzen badute, zerga ezartzeko modukoa, eta jenderik gabeko etxebizitzaren gaineko jabetza-eskubidearen titularrak badira eta, aldi berean, etxebizitza erabiltzeko eskubidea ere berena badute.

3. Baldin eta dena delako jenderik gabeko etxebizitza gozatzeko eskubide erreala jabeari ez badagokio, kanona eskubide erreal horren titularrari ezarriko zaio.

4. Kanona urtero likidatuko da eta jenderik gabeko etxebizitzaren deklarazioa administrazio-bidean behin betiko egintza bihurtzen denetik aurrera. Kanonaren karga 10 euro izango da metro karratu erabilgarri eta urte bakoitzeko, eta \% 10 handituko da etxebizitzak aipatu den egoeran dirauen urte bakoitzeko, hasierako zenbatekoaren hirukoitza gainditu gabe betiere.

\section{9. artikulua. Jenderik gabeko etxebizitza nahitaez alokatzea}

1. Jenderik gabeko etxebizitza deklaratu direnak nahitaez alokatu beharra ezarri ahal izango da baldin eta kokatuta dauden eremuetan etxebizitzaren eskaria eta premia badagoela frogatzen bada, bai bizitegitarako lurzoruen hiri-sektoreetan eta bai berroneratze-eremuetan, hirigune historikoetan, hiri-erdialdeetan, hiri-auzuneetan edo urbanizazioak finkatutako eremuetan, baina, betiere, jenderik gabeko etxebizitza deklaratu badira eta deklaraziotik urtebete igaro eta gero ere okupatu gabe jarraitzen badute. Udalek ezarri ahal izango dute nahitaez alokatu beharra, eta, subsidiarioki, etxebizitza-gaietan eskumena duen Eusko Jaurlaritzako sailak. Azken kasu horretan, dagokion udalari entzun beharko zaio.

2. Nahitaezko desjabetzearen legeriak xedatzen duenaren arabera izapidetuko da nahitaezko alokatzea. Nahitaez alokatu beharra ezartzea bidezkoa dela deklaratu ondoren, etxebizitzaren titularrak berak ordaindu beharko ditu bizigarritasun-baldintzak bermatzeko beharrezko diren egokitze- edo hobekuntza-obren kostuak eta kudeaketa direla-eta Administrazioak bere gain hartutako gastuak.

3. Etxebizitza deskribatzen duen eta nahitaezko alokatzea ezarri beharra dagoela erabakitzen duen administrazio-bideko akordio edo ebazpen irmoan, zehaztu beharko da zer baldintzatan eduki behar den etxebizitza alokatuta eta zenbat iraungo duen alokatze-aldiak, zeina bost urtekoa izango baita gehienez ere, baina beste bost urterainoko nahitaezko luzapena ezartzeko aukerarekin. Errentaria, berriz, Etxebizitza Babestuen eta Zuzkidura Bizitokien Eskatzaileen Erregistroan hautatu beharko da, alokairuko etxebizitzaren eskatzaileen artetik. 
2. atala. Etxebizitzak egoki erabiltzen direla bermatzeko jarduketa publikoak 63. artikulua. Funtzio soziala betetzen ez duten etxebizitzetan Administrazioak esku hartzeko tresna publikoak

1. Etxebizitzak egoki erabiltzen direla eta dagokien funtzio soziala benetan betetzen dutela bermatzeko, eskumena duten administrazioek behar diren sustapen-neurriak hartuko dituzte, eta horiek erregelamendu bidez garatuko dira.

2. Horrez gain, funtzio soziala betetzen ez delako beharrezkoa denean behar bezala arrazoituta, eskumena duten administrazio publikoek esku-hartze administratiboko hainbat neurri hartu ahal izango dute etxebizitzen eta haien titularren gainean. Aurretiaz, edonola ere, administrazio-espedientea osatu beharko da eta interesdunei entzun beharko zaie; espediente horretan, esku hartzeko aukera guztiak aztertu beharko dira, eta justifikatu beharko da ezen hautatzen dela administratuen eskubideei kalterik txikiena egiten diena eta, aldi berean, dena delako kasu jakinean bermatzen duena etxebizitza egoki erabiltzen dela eta bete behar duen funtzio soziala betetzen duela. Hona hemen hartu ahal izango diren neurriak:

a) Lehentasunez eskuratzeko eskubidea eta etxegabetze administratiboa erabiltzea.

b) Jabetza kentzea funtzio soziala ez betetzeagatik.

c) Nahitaezko salmenta edo ordezpena.

d) Exekuzio-aginduak.

e) Jenderik gabeko etxebizitzen gaineko kanona.

f) Nahitaezko alokatzea jenderik gabeko etxebizitzen kasuan.

g) Hertsapen-isunak ezartzea.

h) Zehapenak ezartzea. 


\section{XEDAPEN GEHIGARRIAK}

Bigarrena. Etxebizitzako gastuetarako prestazio osagarria

Etxebizitza-gaietan eskumena duen Eusko Jaurlaritzako sailari dagokio gauzatzea Gizarteratzeko eta Diru Sarrerak Bermatzeko abenduaren 23ko 18/2008 Legean etxebizitzako gastuetarako prestazio osagarriaren arloan Autonomia Erkidegoko Administrazio orokorrari aitortzen zaizkion eskumenak.

Hirugarrena. Irabazi-asmorik gabeko elkarteek bizitegi-multzoak sustatzea edo eskuratzea erabilera-lagapeneko araubidean.

1. Etxebizitzak eta eranskinak partaideen artean esleitzeko asmoz kooperatiben edo bestelako elkarte batzuen bitartez autosustapena edo sustapena egiteko beste modalitate batzuk gorabehera, irabazi-asmorik gabeko elkarte pribatuek etxebizitza-multzo bat higiezin bakar batean sustatu edo eskuratu ahal izango dute, erabilera-lagapeneko araubidean, beren kideen bizitegi-premiak asetzeko, helburu horrekin eratutako elkarteak badira.

2. Kasu horretan, elkartea izango da higiezin-multzoaren jabea, eta jabari osoa izango du haren gainean, edo eraikitzeko aukera ematen dion beste eskubideren bat. Elkartekideak pertsona fisikoak izango dira, eta elkarteak esleitzen dizkien etxebizitzak eta lokalak erabiltzeko eskubidea izango dute baldin eta esleipena haren estatutuetan eta barne-antolakuntzako arauetan aurreikusitako erregelen arabera egiten bada.

3. Halako elkartean erabilera-lagapeneko araubidean bazkide modura sartu nahi duenak diru-kopuru bat ordaindu beharko du, elkarteko gobernu-organoek zehaztuko dutena higiezina sustatu eta mantentzeko kostuen arabera. Sartzeko kopuru hori atzera itzuli egingo da baldin eta ordaindu duenak bere erabilera-eskubidea beste pertsona fisiko bati besterentzen badio, elkarteko gobernu-organoek fiskalizatuta, zeinek bermatu beharko baitute espekulaziozko irabazi edo etekinik ez dagoela aipatutako besterentzean.

4. Elkartekide bakoitzaren erabilera-eskubidea denbora-mugarik gabea da eta halaber «mortis causa» eskualdatu ahal izango da, dituen baldintza eta eduki berberekin. Ordainetan, kanon edo errenta sozial bat pagatu beharko da, eta elkarteak berak erabakiko du zenbatekoa den, hainbat kontzepturen kostuen arabera: sustapena, eraikuntza, amortizazioa, mantenimendua, hobekuntzak eta bizitegitarako higiezinari dagozkion kontzeptu parekagarriak.

5. Erabilera-lagapeneko araubideko elkarteak, xedapen honetan eta xedapen hau garatzeko arauetan aurreikusitakoari heltzen badiote, horretarako ematen zaizkien laguntza publikoen hartzaile izan ahalko dira; elkartearen jabetzako higiezin-multzoa haren titulartasunekoa izango da modu iraunkorrean eta denbora-mugarik gabe, eta ezin izango da jabetza horizontala edo beste edozein jabetzaaraubide pribatu izatera igaro. 